\title{
Synthesis and Structural Characterization of a Double Helical Dinuclear Copper(II) Complex With Tetradentate Biacetyl Bis(benzoylhydrazone)
}

\author{
Rasoul Vafazadeh, ${ }^{1} *$ Najmeh Abdollahi ${ }^{1}$ and Anthony C. Willis ${ }^{2}$ \\ ${ }^{1}$ Department of Chemistry, Yazd University, Yazd, Iran. \\ ${ }^{2}$ Research School of Chemistry, Australian National University, Canberra, ACT 2601, Australia. \\ * Corresponding author: E-mail: (RasoulVafazadeh) rvafazadeh@yazd.ac.ir and rvafazadeh@gmail.com \\ Tel: +983538214778 Fax: +983537250110
}

Received: 06-02-2017

\begin{abstract}
The reaction of tetradentate hydrazone ligand $\mathrm{H}_{2}$ babh with $\mathrm{Cu}\left(\mathrm{CH}_{3} \mathrm{COO}\right)_{2}$ in methanol solvent leads to the formation of the mono-nuclear complex [ $\mathrm{Cu}(\mathrm{babh})]$. However, on being dissolved in dichloromethane solvent and on addition of ethanol solvent, a dinuclear complex of $\left[\mathrm{Cu}_{2}\left(\mu_{1,3} \text {-babh }\right)_{2}\left(\mathrm{C}_{2} \mathrm{H}_{5} \mathrm{OH}\right)_{2}\right]$ is obtained. The X-ray crystallography indicates that the dinuclear helical complex formation is caused due to the unsymmetrical twisting of the $\mathrm{H}_{2}$ babh ligand. One oxygen and two nitrogen atoms from the ligand and one oxygen atom from the other ligand coordinate to each copper(II) center. Both the copper(II) centers in a dinuclear unit are penta-coordinate with a slightly distorted square pyramidal geometry. The IR spectra of mono- and dinuclear copper(II) complexes have different bands. The absorption spectra of mono- and di-nuclear complexes are quite similar in methanol solvent. However, the electronic absorption spectra of the two complexes are basically different in the solid state.
\end{abstract}

Keyword: Copper(II) complex; Hydrazone ligand; Dinuclear; Helical complex; Unsymmetrical twisting

\section{Introduction}

The design and construction of multinuclear transition metal complexes have attracted great interest in recent years because of the role that these metal systems play in a large number of biological processes, molecular magnetic materials, and their variety of structures and interesting properties. ${ }^{1-8}$ Among them, the synthesis and study of multinuclear copper(II) complexes has attracted considerable interest due to exploration of their structures, and also because the function of copper(II) centers in many important biological process. ${ }^{8-12}$

There are a variety of strategies for synthesizing homo- and hetero-multinuclear complexes. The bridging ligands such as halides, pseudo-halides, oxalate, sulfate, etc. have been widely used in the synthesis of multinuclear complexes. ${ }^{13-16}$ In the self-assembly process, the constituent ligands play important roles in the synthesis of polynuclear copper(II) compounds. The most common ligands used for the construction of these complexes are especially Schiff base ligands, which contain potentially

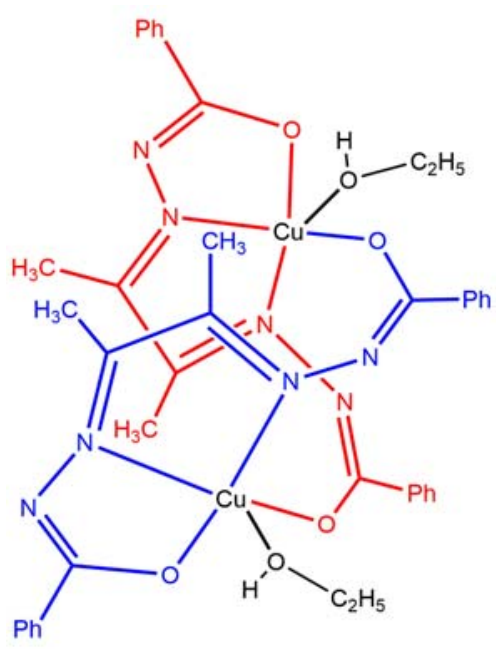

Scheme 1. Structure of dinuclear copper(II) complex

bridging phenoxo or hydroxo oxygen donor atoms..$^{11,17,18}$ The other strategy for the formation of these complexes 
are helicity processes. Helical structures are often formed via a self-assembly process by ligands that connect two or more bidentate coordinating units with appropriate spacers and two or more metal ions. ${ }^{19-21}$

Herein, we have described the synthesis and crystal structures of a dinuclear copper(II) complex double helicates with the tetradentate $\mathrm{N}_{2} \mathrm{O}_{2}$-donor ligand biacetyl bis(benzoylhydrazone), $\mathrm{H}_{2}$ babh (Scheme 1). Also, the structure of the complex is compared with mono- and dinuclear copper(II) complexes that have been previously reported with the $\mathrm{H}_{2}$ babh ligand. ${ }^{21,22}$

\section{Experimental}

\section{1. Materials}

The tetradentate hydrazone ligand, $\mathrm{H}_{2}$ babh, and the mononuclear complex [Cu(babh)] were prepared as previously reported elsewhere by others. ${ }^{21}$ All chemicals were used as supplied by Merck and Fluka without further purification.

\section{2. Physical Measurements}

Infrared spectra were taken with an Equinox 55 Bruker FT-IR spectrometer using $\mathrm{KBr}$ pellets in the 400-4000 $\mathrm{cm}^{-1}$ range. Absorption spectra were determined in the solvent methanol using a GBC UV-Visible Cintra 101 spectrophotometer with $1 \mathrm{~cm}$ quartz, in the range of 200-800 nm at $25^{\circ} \mathrm{C}$. The electronic spectra in the solid state were recorded on a Jasco V-670 UV-VIS spectrophotometer in the range of 200-800 $\mathrm{nm}$. Elemental analyses $(\mathrm{C}, \mathrm{H}, \mathrm{N})$ were performed using a CHNS-O 2400II PERKIN-ELMER elemental analyzer.

\section{3. X-ray Crystallography}

Diffraction images were measured at $150 \mathrm{~K}$ on a Nonius Kappa CCD diffractometer using $\mathrm{Cu} K \alpha$ with graphite monochromator $(\lambda=1.54184 \AA)$. Data was extracted using the CrysAlis PRO Agilent Technologies. The structures were solved by direct methods with the use of SIR92 and refined on $F^{2}$ by full matrix last-squares techniques using the CRYSTALS program package. ${ }^{23,24}$ Crystallographic details are summarized in Table 1.

\section{4 Synthesis of the}

$$
\left[\mathrm{Cu}_{2}\left(\mu_{1,3}-\mathrm{babh}\right)_{2}\left(\mathrm{C}_{2} \mathrm{H}_{5} \mathrm{OH}\right)_{2}\right] \text { Complex }
$$

The $\left[\mathrm{Cu}_{2}\left(\mu_{1,3} \text {-babh }\right)_{2}\left(\mathrm{C}_{2} \mathrm{H}_{5} \mathrm{OH}\right)_{2}\right]$ complex was prepared by first adding the $[\mathrm{Cu}(\mathrm{babh})](0.192 \mathrm{~g}, 0.500$ mmol) complex in dichloromethane solvent $(30 \mathrm{~mL})$. The solution was stirred at room temperature for $2 \mathrm{~h}$. The resulting brown solution was filtered and ethanol $(15 \mathrm{~mL})$ was added to the solution. After two days, crystals of brown needles were obtained by slow evaporation of the
Table 1. Crystallographic data of $\left[\mathrm{Cu}_{2}\left(\mu_{1,3}-\text { babh }\right)_{2}\left(\mathrm{C}_{2} \mathrm{H}_{5} \mathrm{OH}\right)_{2}\right]$ complex

\begin{tabular}{|c|c|}
\hline Compound & {$\left[\mathrm{Cu}_{2}\left(\mu_{1,3}-\mathrm{babh}\right)_{2}\left(\mathrm{C}_{2} \mathrm{H}_{5} \mathrm{OH}\right)_{2}\right]$} \\
\hline Chemical formula & $\mathrm{C}_{40} \mathrm{H}_{44} \mathrm{Cu}_{2} \mathrm{~N}_{8} \mathrm{O}_{6}$ \\
\hline Formula weight & 859.93 \\
\hline Temperature $(K)$ & 150 \\
\hline Space group & Triclinic, $P \overline{1}$ \\
\hline$Z$ & 2 \\
\hline \multicolumn{2}{|l|}{ Unit cell dimensions } \\
\hline$a(\AA)$ & $8.4016(4)$ \\
\hline$b(\AA)$ & $15.5626(5)$ \\
\hline$c(\AA)$ & $16.3803(7)$ \\
\hline$\alpha\left(^{\circ}\right)$ & $101.944(3)$ \\
\hline$\beta\left({ }^{\circ}\right)$ & $104.296(4)$ \\
\hline$\gamma\left({ }^{\circ}\right)$ & $102.394(3)$ \\
\hline$V\left(\AA^{3}\right)$ & $1949.09(15)$ \\
\hline$F(000)$ & 892 \\
\hline$D_{\text {calc }}\left(\mathrm{g} \mathrm{cm}^{-3}\right)$ & 1.465 \\
\hline$\mu\left(\mathrm{mm}^{-1}\right)$ & 1.82 \\
\hline Measured reflections & 21666 \\
\hline Independent reflections & 7466 \\
\hline$R$ (int) & 0.032 \\
\hline Observed reflections & 6388 \\
\hline$R\left[F^{2}>2 \sigma\left(F^{2}\right)\right]$ & 0.035 \\
\hline$w R\left(F^{2}\right)$ (all data) & $0.089^{*}$ \\
\hline
\end{tabular}

${ }^{*} \mathrm{w}=1 /\left[\sigma^{2}\left(\mathrm{~F}^{2}\right)+(0.04 \mathrm{P})^{2}+1.32 \mathrm{P}\right]$, where $\mathrm{P}=\left(\max \left(\mathrm{F}_{\mathrm{o}}{ }^{2}, 0\right)+2 \mathrm{~F}_{\mathrm{c}}{ }^{2}\right) / 3$

solvent. They were isolated by filtration, washed with cold ethanol and dried in air. One of the needle crystals was used for X-ray data collection. The yield was $53 \%$. Anal. Calc. for $\mathrm{C}_{40} \mathrm{H}_{44} \mathrm{Cu}_{4} \mathrm{~N}_{8} \mathrm{O}_{6}: \mathrm{C}, 50.11 ; \mathrm{H}, 3.74 ; \mathrm{N}$, 12.99. Found: $\mathrm{C}, 50.32 ; \mathrm{H}, 3.81 ; \mathrm{N}, 12.74$. IR $(\mathrm{KBr}$, $\left.\mathrm{cm}^{-1}\right): v \mathrm{C}=\mathrm{N}=1619, v \mathrm{C}=\mathrm{C}($ aromatic $)=1476, v \mathrm{C}-\mathrm{N}=$ 1368 and $v \mathrm{C}-\mathrm{O}=1206$.

\section{Results and Discussion}

\section{1. Characterization of the Complex}

A comparison of the IR spectra of the free ligand and mononuclear, $\mathrm{Cu}(\mathrm{babh})$, and dinuclear, $\left[\mathrm{Cu}_{2}\left(\mu_{1,3}-\right.\right.$ babh $)_{2}\left(\mathrm{C}_{2} \mathrm{H}_{5} \mathrm{OH}\right)_{2}$ ], complexes indicates that the ligand is coordinated to the copper(II) center. The IR spectrum of the $\mathrm{H}_{2}$ babh ligand, shows bands at 1600 and $1651 \mathrm{~cm}^{-1}$, which are assigned as $v \mathrm{C}=\mathrm{N}$ and $v \mathrm{C}=\mathrm{O}$, respectively. In the IR spectra mono- and di-nuclear, the strong bands at 1613 and $1619 \mathrm{~cm}^{-1}$ are assigned to $v \mathrm{C}=\mathrm{N}$, respectively. The IR spectra of mono- and di-nuclear copper(II) complexes have different bands at the range of 1000-1600 $\mathrm{cm}^{-1}$.

The electronic absorption spectra were recorded for copper(II) complexes in various solvents, methanol, ethanol, dichloromethane and $N, N^{\prime}$-dimethylformamide (DMF) in the visible and UV regions. The absorption spectra of mono- and dinuclear $\mathrm{Cu}(\mathrm{II})$ complexes are qui- 
te similar in studied solvents. The spectra exhibit one maximum at $642 \mathrm{~nm}$ which can be attributed to the d-d transition. Two bands at 446 and $274 \mathrm{~nm}$ are due to intraligand $\pi-\pi^{*}$ and $n-\pi^{*}$ transition, respectively. ${ }^{11-13,25}$ Therefore, we can conclude that the dinuclear copper(II) complex in the solvent is converted to mononuclear complex.

The electronic spectra of the complexes were recorded also in the solid state. The electronic absorption spectra of the two complexes are basically different in the solid state (Fig. 1). Both complexes exhibit a band in the region $265 \mathrm{~nm}$ due to intraligand transition. The broad band is centered at $410 \mathrm{~nm}$ for the dinuclear complex and two bands at 547 and $423 \mathrm{~nm}$ for the mononuclear complex are attributed to LMCT transitions. ${ }^{21}$ The bands at 628 and $661 \mathrm{~nm}$ are assigned to $\mathrm{d}-\mathrm{d}$ transition for di- and mononuclear complexes, respectively. This shift in position of $\mathrm{d}-\mathrm{d}$ transition may be explained in terms of the change in the coordination number and the presence of different coordination environments for the copper(II) ions in the two complexes.

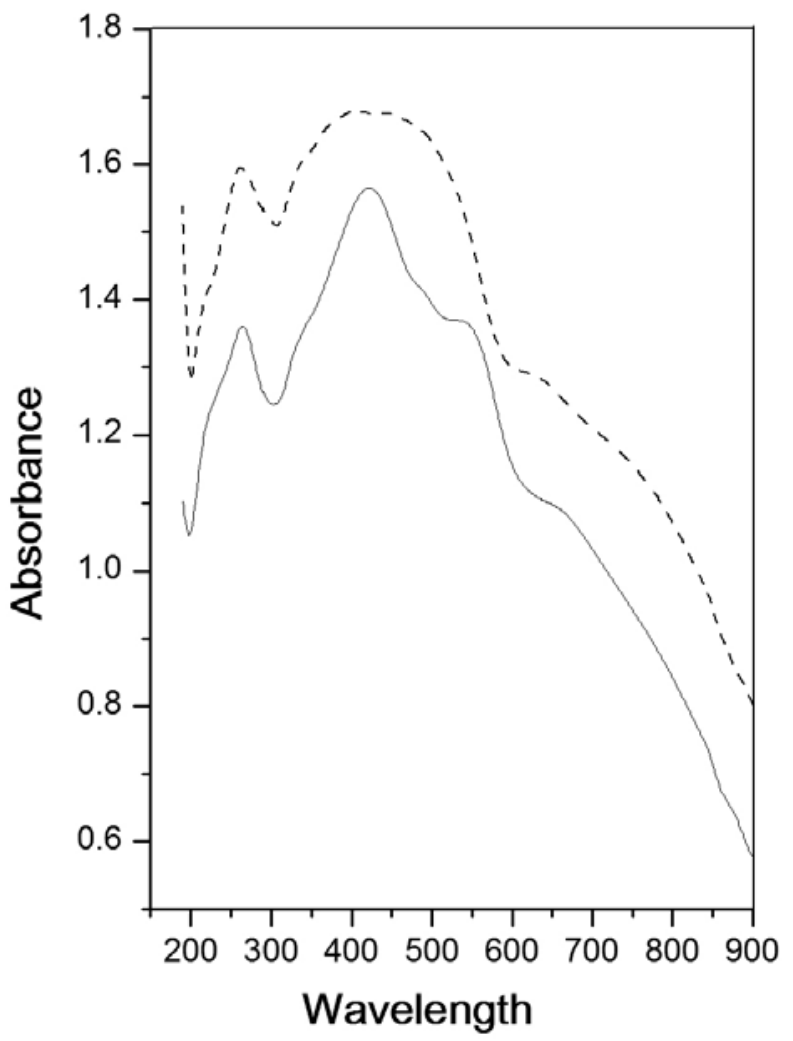

Fig. 1. The solid state electronic spectra of $[\mathrm{Cu}(\mathrm{babh})]$ ( - ) and $\left[\mathrm{Cu}_{2}\left(\mu_{1,3}-\text { babh }\right)_{2}\left(\mathrm{C}_{2} \mathrm{H}_{5} \mathrm{OH}\right)_{2}\right](----)$

\section{2. Description of Crystal Structure of the Complex}

The single crystal X-ray diffraction data for the complex is listed in Table 1. A structural representation and selected interatomic distances and angles of the complex are presented in Fig. 2 and Table 2. The complex crystallizes in the triclinic space group $\mathrm{P} \overline{1}$. The asymmetric unit consists of two $\mathrm{Cu}(\mathrm{II})$ ions, two babh ${ }^{2-}$ ligands, and two coordinated ethanol molecules (Fig. 2). There is disorder in the packing of one of the ethanol species over two positions have relative occupancies which refined to $57 \%: 43 \%$.

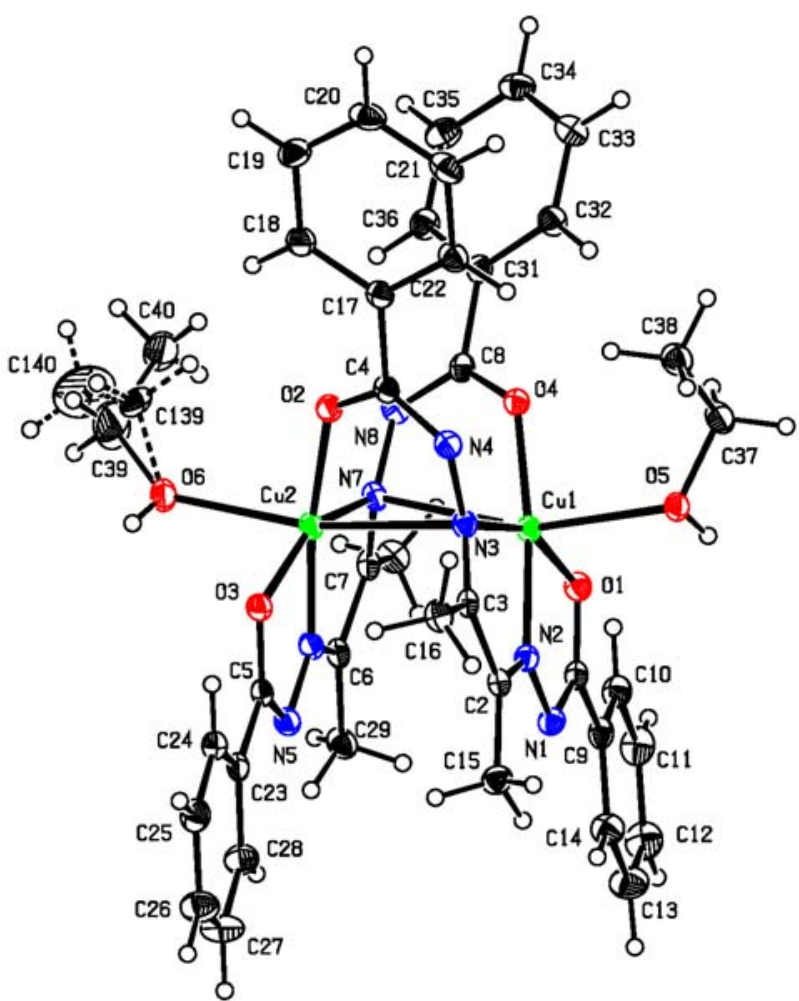

Fig. 2. The structure of the $\left[\mathrm{Cu}_{2}\left(\mu_{1,3}-\text { babh }\right)_{2}\left(\mathrm{C}_{2} \mathrm{H}_{5} \mathrm{OH}\right)_{2}\right]$ complex, with labelling of selected atoms. Anisotropic displacement ellipsoids exhibit $30 \%$ probability levels. Hydrogen atoms are drawn as circles with small radii

Table 2. Selected bond lengths $(\AA)$ and angles $\left(^{\circ}\right)$ in $\left[\mathrm{Cu}_{2}\left(\mu_{1,3}\right.\right.$ babh $)_{2}\left(\mathrm{C}_{2} \mathrm{H}_{5} \mathrm{OH}\right)_{2}$ ] complex

\begin{tabular}{llll}
\hline $\mathrm{Cu} 1-\mathrm{O} 1$ & $2.0402(15)$ & $\mathrm{O} 1-\mathrm{Cu} 1-\mathrm{O} 5$ & $90.41(6)$ \\
$\mathrm{Cu} 1-\mathrm{O} 4$ & $1.9062(15)$ & $\mathrm{O} 1-\mathrm{Cu} 1-\mathrm{O} 4$ & $101.83(6)$ \\
$\mathrm{Cu} 1-\mathrm{O} 5$ & $2.2883(16)$ & $\mathrm{O} 4-\mathrm{Cu} 1-\mathrm{O} 5$ & $92.04(6)$ \\
$\mathrm{Cu} 1-\mathrm{N} 2$ & $1.9212(18)$ & $\mathrm{O} 1-\mathrm{Cu} 1-\mathrm{N} 2$ & $78.78(7)$ \\
$\mathrm{Cu} 1-\mathrm{N} 3$ & $2.0604(18)$ & $\mathrm{O} 4-\mathrm{Cu} 1-\mathrm{N} 2$ & $173.64(7)$ \\
$\mathrm{Cu} 2-\mathrm{O} 2$ & $1.9041(15)$ & $\mathrm{O}-\mathrm{Cu} 1-\mathrm{N} 2$ & $94.29(7)$ \\
$\mathrm{Cu} 2-\mathrm{O} 3$ & $2.0568(15)$ & $\mathrm{O} 1-\mathrm{Cu} 1-\mathrm{N} 3$ & $157.40(7)$ \\
$\mathrm{Cu} 2-\mathrm{O} 6$ & $2.2644(17)$ & $\mathrm{O} 3-\mathrm{Cu} 2-\mathrm{O} 6$ & $87.98(6)$ \\
$\mathrm{Cu} 2-\mathrm{N} 6$ & $1.6213(18)$ & $\mathrm{O} 2-\mathrm{Cu} 2-\mathrm{O} 3$ & $104.25(6)$ \\
$\mathrm{Cu} 2-\mathrm{N} 7$ & $2.0658(19)$ & $\mathrm{O} 2-\mathrm{Cu}-\mathrm{O} 6$ & $93.94(7)$ \\
$\mathrm{Cu} 1 \mathrm{~N} 7$ & $2.7494(18)$ & $\mathrm{O} 3-\mathrm{Cu} 2-\mathrm{N} 7$ & $156.91(7)$ \\
$\mathrm{Cu} 2 \mathrm{~N} 3$ & $2.7254(19)$ & $\mathrm{O} 2-\mathrm{Cu} 2-\mathrm{N} 6$ & $172.20(7)$ \\
$\mathrm{C} 1-\mathrm{O} 1$ & $1.289(3)$ & $\mathrm{O} 6-\mathrm{Cu} 2-\mathrm{N} 7$ & $98.26(7)$ \\
$\mathrm{C} 1-\mathrm{N} 1$ & $1.331(3)$ & $\mathrm{N} 2-\mathrm{N} 1-\mathrm{C} 1$ & $108.21(18)$ \\
$\mathrm{C} 2-\mathrm{N} 2$ & $1.290(3)$ & $\mathrm{N} 2-\mathrm{C} 2-\mathrm{C} 3$ & $113.09(19)$ \\
\hline
\end{tabular}


From the crystal structure and based on the bond lengths between the copper and coordinating atoms, it has been found that in the complex, two copper(II) centers are penta-coordinate with a $\mathrm{N}_{2} \mathrm{O}_{3}$ donor. Coordination geometry about each copper(II) ion is essentially a distorted square pyramid with one oxygen atom and two nitrogen atoms from the ligand, one oxygen atom from ethanol molecule and one oxygen atom from the other ligand of the dinuclear complex. The four equatorial positions are occupied by two nitrogen atoms (N2 and N3), one oxygen atom (O1) from one hydrazone ligand and the fourth position is occupied by the oxygen atom $(\mathrm{O} 4)$ of the other ligand of the dinuclear complex. The axial position is occupied by one oxygen atom (O5) of the ethanol molecule. The axial $\mathrm{Cu}-\mathrm{O} 5$ bond is 2.2883(16) $\AA$ which is longer than the equatorial $\mathrm{Cu}-\mathrm{O}$ ones [1.9062(15) and 2.0402(15) $\AA$ ], and consistent with analogous systems observed in the literature. ${ }^{27-30}$ The coordination spheres of the copper(II) ions in the complex are best described as a distorted square pyramidal according to the Addison parameter $\tau$ values of 0.27 (for $\mathrm{Cu} 1$ ) and 0.25 (for $\mathrm{Cu} 2$ ). The parameter $\tau$ is defined as $\tau=(\alpha-\beta) / 60, \alpha>\beta$, where $\alpha$ and $\beta$ are the largest angles; with $\tau=1$ for a regular trigonal bipyrmid and $\tau=0$ for a regular square pyramid. ${ }^{31}$ The copper(II) ion is displaced from the basal plane of $\mathrm{N}_{2} \mathrm{O}_{2}$ by $0.116 \AA$ towards the apical oxygen atom. The $\mathrm{Cu} \cdots \mathrm{Cu}$ distance is $3.149 \AA$.

The comparison of $\mathrm{C}-\mathrm{O}$ and $\mathrm{C}-\mathrm{N}$ bond lengths of the hydrazone ligand is a useful techniques in identifying the mode of bonding of the ligand (keto or enol) to the metal ion. ${ }^{32}$ The $\mathrm{C} 1-\mathrm{O} 1$ and $\mathrm{C} 8-\mathrm{O} 4$ bond lengths of complex (1.289(3) and 1.283(3) $\AA$, respectively) and C1-N1 and C8-N8 (1.331(3) and 1.314(3) $\AA$, respectively) are si- milar and are in good agreement with analogous $\mathrm{Cu}(\mathrm{II})$ complexes observed in the literature where a hydrazone ligand coordinates to the $\mathrm{Cu}(\mathrm{II})$ center in its iminolate form. ${ }^{2,13,14,25,33}$

The average of $\mathrm{Cu}-\mathrm{O}$ bond lengths in the dinuclear complex $(1.978 \AA)$ is very similar to the corresponding distances in previously reported mononuclear copper(II) complex $(1.978 \AA) .{ }^{22}$ However, the average of $\mathrm{Cu}-\mathrm{N}$ bond lengths in the dinuclear complex (1.992 $\AA$ ) is longer than the corresponding bonds in mononuclear copper(II) complex $(1.918 \AA) .{ }^{22}$ The differences are perhaps due to the difference in the coordination modes and the twisting of ligand $\mathrm{babh}^{2-}$ along the $-\mathrm{C}=\mathrm{N}-\mathrm{N}=\mathrm{C}-$ single bond for the coordination of the ligand to the copper(II) ions in the formation of $\left[\mathrm{Cu}_{2}\left(\mu_{1,3} \text {-babh }\right)_{2}\left(\mathrm{C}_{2} \mathrm{H}_{5} \mathrm{OH}\right)_{2}\right]$.

The dinuclear helical complex formation is caused by the unsymmetrical twisting along the $-\mathrm{C}=\mathrm{N}-\mathrm{N}=\mathrm{C}-$ single bond and two nitrogen atoms and one oxygen from each ligand are coordinated to each copper(II) center. In the dinuclear complex reported by $\mathrm{Pal}^{21}$ the complex was formed by symmetrical twisting around the central $\mathrm{C}-\mathrm{C}$ single bond in fragment of $=\left(\mathrm{CH}_{3}\right) \mathrm{C}-\mathrm{C}\left(\mathrm{CH}_{3}\right)=$. One nitrogen atom and one oxygen from each ligand of babh was coordinated to each copper(II) center.

The single crystal X-ray analyses indicate the presence of non-covalent interactions between the nitrogen atom of the imine group of the ligand and the other copper(II) center in the dinuclear complex. The distance between $\mathrm{Cu} 1$ and $\mathrm{Cu} 2$ centers and the $\mathrm{N}$ atoms of the imine group is 2.750(1) $\AA$ for Cu1-N7 and 2.725(1) $\AA$ for $\mathrm{Cu} 2-\mathrm{N} 3$, respectively, which suggests a weak non-covalent interaction.

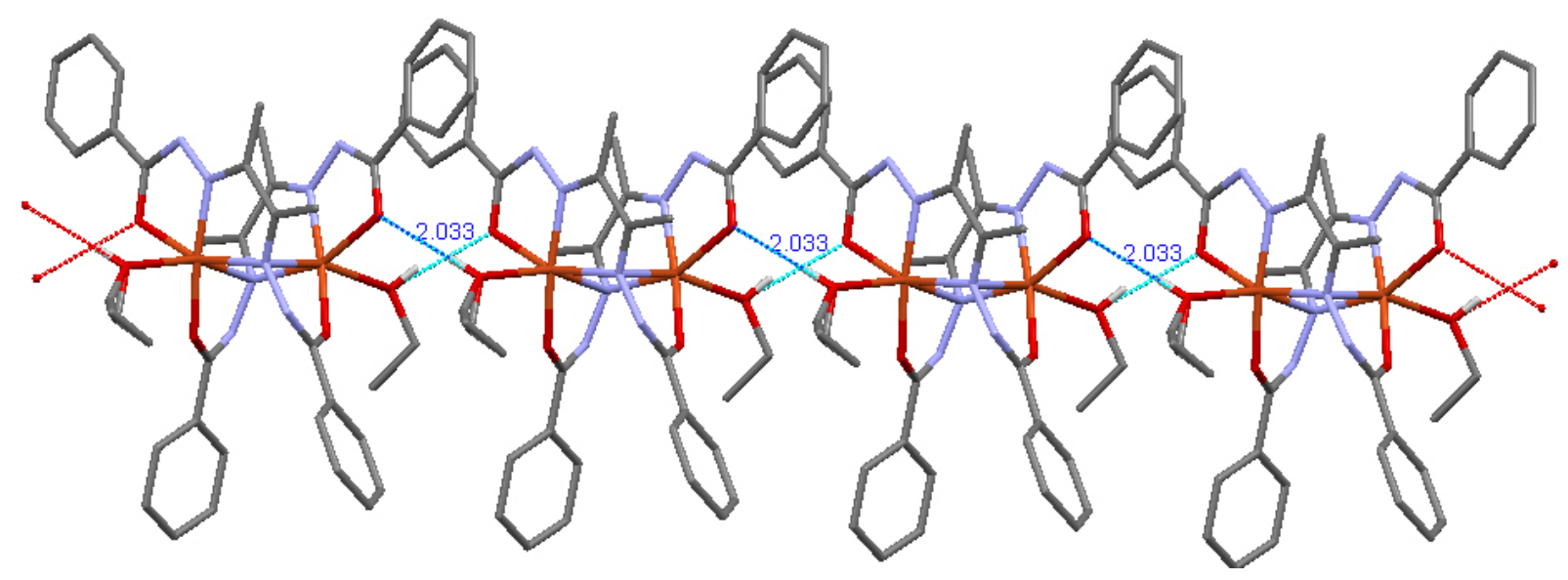

Fig. 3. Various hydrogen bonding interactions, $\mathrm{O}-\mathrm{H} \cdots \mathrm{O}$ in $\left[\mathrm{Cu}_{2}\left(\mu_{1,3}-\mathrm{babh}\right)_{2}\left(\mathrm{C}_{2} \mathrm{H}_{5} \mathrm{OH}\right)_{2}\right]$ complex, other hydrogen atoms are omitted for clarity.

Table 3. Hydrogen bonding $(\AA)$ and angles $\left(^{\circ}\right)$ for $\left[\mathrm{Cu}_{2}\left(\mu_{1,3}-\text { babh }\right)_{2}\left(\mathrm{C}_{2} \mathrm{H}_{5} \mathrm{OH}\right)_{2}\right]$ complex

\begin{tabular}{|c|c|c|c|c|c|}
\hline$\overline{D-H} \cdots A$ & D-H & $H \cdots A$ & $D \cdots A$ & D-H $\cdots A$ & Symmetry code \\
\hline $\mathrm{O} 5-\mathrm{H} 1 \cdots \mathrm{O} 3$ & $0.76(3)$ & $2.03(3)$ & $2.776(5)$ & $166(3)$ & $x+1, y, z$ \\
\hline $\mathrm{O} 6-\mathrm{H} 2 \cdots \mathrm{O} 1$ & $0.71(4)$ & $2.13(4)$ & $2.841(5)$ & 171(4) & $x-1, y, z$ \\
\hline
\end{tabular}

Vafazadeh et al.: Synthesis and Structural Characterization ... 
Dinuclear complexes are involved in intermolecular $\mathrm{O} 5-\mathrm{H} 1 \cdots \mathrm{O} 3(x-1, y, z)$ and $\mathrm{O} 6-\mathrm{H} 2 \cdots \mathrm{O} 1(x+1, y, z)$ hydrogen bonding interactions between coordinated ethanol molecules and the oxygen atoms of a neighboring babh $^{2-}$ ligands (Fig. 3). The details of the hydrogen bonding are given in Table 3.

\section{Conclusion}

The new homo-dinuclear complex $\left[\mathrm{Cu}_{2}\left(\mu_{1,3}-\mathrm{babh}\right)_{2}\right.$ $\left.\left(\mathrm{C}_{2} \mathrm{H}_{5} \mathrm{OH}\right)_{2}\right]$ has been synthesized and the crystal structure of the complex has been determined. Single crystal $\mathrm{X}$-ray diffraction indicate that the dinuclear helical complex formation was caused due to the unsymmetrical twisting of the ligand, $\mathrm{N}_{2} \mathrm{O}_{2}$ along the $-\mathrm{C}=\mathrm{N}-\mathrm{N}=\mathrm{C}-$ single bond. Two nitrogen atoms and one oxygen from each ligand are coordinated to each copper(II) center. Two copper(II) centers are penta-coordinate with a $\mathrm{N}_{2} \mathrm{O}_{3}$ donor. Coordination geometry about each copper (II) ion is essentially a square pyramid with one oxygen atom and two nitrogen atoms from the ligand, one oxygen atom from an ethanol molecule, and one oxygen atom from the other ligand of the dinuclear complex. The absorption spectra of mono- and di-nuclear complexes are quite similar in solvent. However, the electronic absorption spectra of two the complexes are basically different in the solid state.

\section{Supplementary Material}

The deposition numbers of the studied dinuclear complex is CCDC 1527221. These data can be obtained free-of-charge via www.ccdc.cam.ac.uk/data_request/cif, by emailing data-request @ ccdc.cam.ac.uk, or by contacting The Cambridge Crystallographic Data Centre, 12 Union Road, Cambridge CB2 1EZ, UK; fax +44 1223 336033.

\section{Acknowledgments}

The authors are grateful to the Yazd University (YU) and the Australian National University (ANU) for partial support of this work.

\section{References}

1. E. I. Solomon, D. E. Heppner, E. M. Johnston, J. W. Ginsbach, J. Cirera, M. Qayyum, M. T. Kieber-Emmons, C. H. Kjaergaard, R. G. Hadt, L. Tian, Chem. Rev. 2014, 114, 3659-3853. https://doi.org/10.1021/cr400327t

2. R. Vafazadeh, B. Khaledi, A. C. Willis, M. Namazian, Polyhedron 2011, 30, 1815-1819.

https://doi.org/10.1016/j.poly.2011.04.026
3. R. Vafazadeh, A. C. Willis, Acta Chim. Slov. 2016, 63, 186-192. https://doi.org/10.17344/acsi.2016.2263

4. R. Vafazadeh, B. Khaledi, A. C. Willis, Acta Chim. Slov. 2012, 59, 954-958.

5. X. Z. Zhang, Y. Gu, Y. Li, A. Liu, F. Liu, Z. You, H. L. Zhu, Acta Chim. Slov. 2016, 63, 721-725. https://doi.org/10.17344/acsi.2016.2421

6. B. Ardan, Y. Slyvka, E. Goreshnik, M. Mys'kiv, Acta Chim. Slov. 2013, 60, 484-490.

7. B. Dojer, A. Pevec, F. Belaj, M. Kristl, Acta Chim. Slov. 2015, 62, 312-318. https://doi.org/10.17344/acsi.2014.1111

8. Z. Li- Hua, W. Wei-Na, W. Yuan, S. Guang, J. Coord. Chem. 2013, 66, 227-242.

9. A. Galani, E. K. Efthimiadou, G. Mitrikas, Y. Sanakis, V. Psycharis, C. Raptopoulou, G. Kordas, A. Karaliota, Inorg. Chim. Acta, 2014, 423, 207-218. https://doi.org/10.1016/j.ica.2014.08.005

10. G. Y. Li, K. J. Du, J. Q. Wang, J. W. Liang, J. F. Kou, X. J. Hou, L. N. Ji, H. Chao, J. Inorg. Biochem. 2013, 119, 43-53. https://doi.org/10.1016/j.jinorgbio.2012.09.019

11. R. Vafazadeh, F. Jafari, M. M. Heidari, A.C. Willis, J. Coord. Chem. 2016, 69, 1313-1325. https://doi.org/10.1080/00958972.2016.1163547

12. R. Vafazadeh, N. Hasanzade, M. M. Heidari, A.C. Willis, Acta Chim. Slov. 2015, 62, 122-129. https://doi.org/10.17344/acsi.2014.797

13. R. Vafazadeh, Z. Moghadas, A. C. Willis, J. Coord. Chem. 2015, 68, 4255-4271.

14. R. Vafazadeh, R. Esteghamat-Panah, A. C. Willis, A. F. Hill, Polyhedron 2012, 48, 51-57. https://doi.org/10.1016/j.poly.2012.08.057

15. J.R. Zimmerman, A. Bettencourt-Dias, Inorg. Chem. Commun. 2011, 14, 753-758. https://doi.org/10.1016/j.inoche.2011.02.028

16. R. Pedrido, M.J. Romero, M.R. Bermejo, M. Martinez-Calvo, A.M. Gonzalez-Noyab, G. Zaragoza, Dalton Trans. 2009, 8329-8340. https://doi.org/10.1039/b908782f

17. R. Vafazadeh, A. C. Willis, J. Coord. Chem. 2015, 68, 22402252. https://doi.org/10.1080/00958972.2015.1048688

18. D. Venegas-Yazigi, D. Aravena, E. Spodine, E. Ruiz, S. Alvarez, Coord. Chem. Rev. 2010, 254, 2086-2095. https://doi.org/10.1016/j.ccr.2010.04.003

19. M. A. Sharif, G. R. Najafi, Acta Chim. Slov. 2013, 60, 138143.

20. Y. Lan, G. Novitchi, R. Clerac, J. K. Tang, N. T. Madhu, I. J. Hewitt, C. E. Anson, S. Brooker, A. K. Powell, Dalton Trans. 2009, 1721-1727. https://doi.org/10.1039/b818113f

21. T. Ghosh, S. Pal, Inorg. Chim. Acta 2010, 363, 3632-3636. https://doi.org/10.1016/j.ica.2010.07.007

22. T. Ghosh, A. Mukhopadhyay, K. S. C. Dargaiah, S. Pal, Struct. Chem. 2010, 21, 147-152. https://doi.org/10.1007/s11224-009-9557-2

23. A. Altomare, G. Cascarano, G. Giacovazzo, A. Guagliardi, M. C. Burla, G. Polidori, M. Camalli, J. Appl. Cryst. 1994, $27,435-436$. 
24. P. W. Betteridge, J. R. Carruthers, R. I. Cooper, K. Prout, D.J. Watkin, J. Appl. Cryst. 2003, 36, 1487-1487. https://doi.org/10.1107/S0021889803021800

25. R. Vafazadeh, M. Alinaghi, A. C. Willis, A. Benvidi, Acta Chim. Slov. 2014, 61, 121-125.

26. R. Vafazadeh, V. Hayeri, A. C. Willis, Polyhedron 2010, 29 , 1810-1814. https://doi.org/10.1016/j.poly.2010.02.030

27. X.-J. Li, K. Zheng, Y.-T. Li, C.-W. Yan, Z.-Y. Wu, S.-Y. Xuan, J. Coord. Chem. 2015, 68, 928-948. https://doi.org/10.1080/00958972.2015.1009452

28. D. Barut, N. Korkmaz, S. T. Astley, M. Aygün, Acta Chim. Slov. 2015, 62, 88-94.

https://doi.org/10.17344/acsi.2014.734
29. A. Ray, C. Rizzoli, G. Pilet, C. Desplanches, E. Garribba, E. Rentschler and S. Mitra, Eur. J. Inorg. Chem. 2009, 29152928. https://doi.org/10.1002/ejic.200900188

30. A. Biswas, M. G. B. Drew, J. Ribas, C. Diaz, A. Ghosh, Eur. J. Inorg. Chem. 2011, 2405-2412. https://doi.org/10.1002/ejic.201100067

31. A. W. Addison, N. Rao, J. Reedijk, J.V. Rijn, G.C. Verschoor, J. Chem. Soc. Dalton Trans. 1984, 1349-1356. https://doi.org/10.1039/DT9840001349

32. T. Ghosh, S. Pal, J. Chem. Sci. 2015, 127, 1201-1209. https://doi.org/10.1007/s12039-015-0887-x

33. M. Nandy, D. L. Hughes, G. M. Rosair, R. K. B. Singh, S. Mitra, J. Coord. Chem. 2014, 67, 3335-3353. https://doi.org/10.1080/00958972.2014.964697

\section{Povzetek}

Reakcija štiriveznega hidrazonskega liganda $\mathrm{H}_{2}$ babh z $\mathrm{Cu}\left(\mathrm{CH}_{3} \mathrm{COO}\right)_{2}$ v metanolu vodi do nastanka enojedrnega kompleksa $[\mathrm{Cu}($ babh $)]$. Po raztapljanju v diklorometanu in ob dodatku etanola nastane dvojedrni kompleks $\left[\mathrm{Cu}_{2}\left(\mu_{1,3}{ }^{-}\right.\right.$ babh $)_{2}\left(\mathrm{C}_{2} \mathrm{H}_{5} \mathrm{OH}\right)_{2}$ ]. Rentgenska kristalografija razkrije, da zaradi nesimetričnega zvitja $\mathrm{H}_{2}$ babh liganda nastane dvojedrni kompleks z vijačno strukturo. En kisikov in dva dušikova atoma z liganda in en kisik z drugega liganda se koordinirajo na posamezen bakrov(II) center. Oba bakrova(II) centra v dvojedrni enoti sta pentakoordinirana $\mathrm{z}$ delno popačeno kvadratno-piramidalno geometrijo. IR spektra eno- in dvojedrnega bakrovega(II) kompleksa imata različne trakove. Absorpcijska spektra eno- in dvojedrnega kompleksa v metanolu sta zelo podobna, medtem ko se elektronska absorpcijska spektra obeh kompleksov v trdnem stanju delno razlikujeta. 